\title{
Industry-Level Wage Bargaining: A Partial Rehabilitation - The German Experience - ${ }^{1}$
}

\section{Bernd Fitzenberger ${ }^{2}$ and Wolfgang Franz ${ }^{3}$}

May 1999

\begin{abstract}
In order to reduce unemployment, it is often recommended that industrylevel wage bargaining in Germany should be replaced by a more decentralized system. This paper provides a critical assessment of the current wage bargaining institutions and reexamines the case for a more decentralized system. Based on a theoretical model integrating Insider-Outsider aspects into the comparison, the uniformly superior employment performance of a decentralized wage bargaining system is questioned. We conclude that, rather than solely trying to decentralize wage bargaining, a promising policy option may be to improve the skills of the unemployed by efficient labour market policies and to foster institutional reforms such that wage bargaining takes account of the long-run employment consequences of wage setting.
\end{abstract}

Keywords: Centralization of Wage Bargaining, Union Preferences, Insider-Outsider Theory, Germany

JEL Classification: J51, J31

\section{Introduction}

According to conventional wisdom fully decentralized wage bargaining systems outperform wage settlements at a medium centralized level such as sectoral or industry-level wage bargaining. If so, one promising candidate for explaining persistent unemployment can be identified for those countries with industry-level wage bargaining, such as Germany. Moreover, the obvious cure for solving parts of the problem of joblessness is to give room for wage bargaining exclusively on the firm level.

Our paper challenges this view to some extent. The argument is that fully decentralized wage bargaining may be superior in some cases, however, this result is anything but certain in others. Therefore, the demands for a radical change of the (German) wage

\footnotetext{
${ }^{1}$ We are grateful to Thiess Büttner, Herbert S. Buscher, and Peter Winker for helpful comments.

${ }^{2}$ Dresden University of Technology.

${ }^{3}$ Centre for European Economic Research (ZEW), Mannheim and University of Mannheim.
} 
system, which are frequently announced in the public, are often too far reaching.

The motivation of our paper is twofold. First, the German wage bargaining system has come under severe attack. The institutional setting of industry wage bargaining is viewed as sharing major responsibility for wages being too inflexible both with respect to their level and their dispersion. Indeed, there is virtually no disagreement that more flexibility in the wage bargaining outcomes is in order. While this goes without saying, it is another question whether achieving this flexibility requires wage bargaining at the firm level. More precisely, as long as it can be shown that, on theoretical grounds, decentralized wage bargaining does not always outperform (slightly) more centralized wage settlements, an alternative, if not better, strategy would keep the existing industry-level wage bargaining system and try to render it more flexible.

Second, a serious deficiency of the well known Calmfors-Driffill (1988) U-hypothesis and its variants, that both decentralized and centralized wage bargaining outperform industry-level bargaining, is the lack of, or at least unsatisfactory, integration of Insider-Outsider aspects. Our paper attempts to enrich the existing theoretical literature. It comes as a surprise that analyses of the optimal degree of centralization of wage bargaining did not take into account more seriously the Insider-Outsider aspect because even proponents of decentralized bargaining admit that Insider power might be more relevant at the firm level than at the industry level. ${ }^{4}$ Moreover, previous work by the authors has shown that some implications of the theoretical literature on the Calmfors-Driffill-hypothesis, which can be tested empirically, are inconsistent with facts: On the basis of estimated wage equations for several EU-countries no significant differences could be found which can be attributed to low or high centralization of wage bargaining. ${ }^{5}$ Despite the limits of that approach some doubts on the validity of the Calmfors-Driffill-hypothesis could be established. Hence, the obvious question is whether the failure to integrate Insider-Outsider aspects can serve as an explanation of the limited empirical evidence concerning the superiority of decentralized bargaining. Indeed, this is a major argument put forward in this paper.

\footnotetext{
${ }^{4}$ See, for example, Berthold and Fehn (1996).

${ }^{5}$ Fitzenberger and Franz (1994).
} 
The remainder of this paper is organized as follows. As a prerequisite for the theoretical considerations the next section engages in setting the scene by very briefly describing the institutional framework and some basic facts with respect to wage bargaining in Germany. In addition, this section also raises some doubts as to whether fully decentralized wage bargaining always does better than industry wage settlements. Section 3 is devoted to the theoretical analysis. Section 4 puts the theoretical results in perspective and concludes.

\section{Institutional Background and Basic Facts}

As a prerequisite for the following analysis, it is necessary to review briefly the institutional regulations concerning the wage bargaining process and to add some basic quantitative facts.

Wage bargaining in Germany typically takes place at the sectoral or industry and regional level such as for the metal and electrical industry in northern Baden-Württemberg (one of the 16 states in Germany). While the outcome of this wage settlement concerns, strictly speaking, only union members in firms which belong to the respective regional employers' association, it is routinely extended to the overwhelming number of employees in this sector or industry. There are three reasons for this.

First, despite being a member in the aforementioned employers' association, the firm is free on legal grounds to make other wage contracts with non-unionized employees. ${ }^{6}$ However, most if not all firms make a reference to the collective wage settlement in wage contracts regardless of whether the worker is a union member or not. Besides avoiding internal disputes, the major reason is that the worker presumably would join the union after being hired for a wage rate less than the negotiated wage rate so that the firm automatically had to pay the negotiated wage rate (union deterrence effect).

Second, the firm can choose not to become a member of the employers' association or to leave it. In the latter case, however, the firm is committed to the negotiated

\footnotetext{
${ }^{6}$ Union membership must not, however, serve as a selection criterion for different wage contracts.
} 
wage rate until the collective agreement expires. Firms not subject to collective wage settlements bargain over wages (and other topics) with the works council which is mostly dominated by union members or, in the absence of a works council, make firm specific wage agreements. Basically any wage rate can be agreed upon but there exist legal restrictions. Most importantly, a severe legal restriction prohibits employers, even if they are not member of the respective employers' association, from making a wage contract with their works council which undercuts a negotiated wage settlement unless this wage settlement explicitly gives room for such firm specific contracts. ${ }^{7}$ Such wage bargains must be made individually with each employee. Another restriction, albeit virtually not binding, is the possibility that the government can enact a wage floor if wage agreements do not meet necessary social and economic needs of workers. This law, however, has never been applied since 1952 when it was introduced. Despite some wage flexibility, a considerable (but declining) number of firms which are not members of the employers' association nevertheless pay at least the negotiated wage rates, e.g. in order to avoid internal disputes with the works council or to maintain competitiveness with other firms when hiring workers.

Third, wage settlements in one region and for a specific sector or industry serve as guidelines for others. Not only are regional outcomes of wage bargainings transferred with slight modifications, if any at all, to the remaining regions, but also other sectors take the negotiated wage increases of the "leading" sector in the annual wage round as a serious signal (pattern bargaining). An important explanation is that of competition among union leaders.

Table 1 displays the coverage of industry wage bargaining with respect to both firms and employees. Considerable differences exist between East and West Germany and between sectors. In West Germany around one half of all firms and two thirds of all employees are explicitly covered by industry wage settlements. The respective figures for East Germany fall short of these numbers to a non-negligible extent. As will be discussed below, one reason for the lower coverage in East Germany is the wage policy there. In order to circumvent the enormous catching up process of East German

\footnotetext{
${ }^{7}$ This is $\oint 77,3$ of the Betriebsverfassungsgesetz (law on labour relations in the firm).
} 
wages, many existing firms left their employers' association or newly established firms refrained from joining the association. Table 1 also highlights substantial sectoral differences within and between both German regions. Taken together, the majority of employees in Germany is already covered explicitly by collective bargaining. Moreover, when employees whose wage contracts refer to collective wage settlements are included, then a guess-estimate of around 90 percent of all employees are covered by collective bargaining.

This high coverage stands in marked contrast to union membership in Germany especially if compared with other European countries. In West Germany, the share of union members among all employees amounts to around 30 percent (in 1995), compared with around 80 percent or more in Scandinavia, more than 40 percent in Austria and Italy, and around 33 percent in the UK, but it is higher compared to the 9 percent figure in France.

In recent years, collective wage settlements have come under severe pressure in Germany. This is most evident for East Germany. Not only does coverage in East Germany fall short substantially of West German figures but also a non-negligible number of firms, although subject to industry wage settlements, pay less than negotiated wages - with more or less tacit consent by the works council. Figures exist for East Germany in 1994, that show that some 14 percent of all firms, bound to collective bargaining, nevertheless paid lower than standard wages. ${ }^{8}$ That means, these firms and their works council had, strictly speaking, to commit a breach of the collective wage contract in order to ensure their economic survival.

Of course, this drawback of medium level wage bargaining is consistent with the technical outcome predicted by the standard Calmfors-Driffill-hypothesis [Calmfors (1993)]. For this reason, it does not come as a surprise that quite a few economists in Germany demanded (more or less) fully decentralized wage bargaining. ${ }^{9}$ Another group of economists - such as the German Council of Economic Experts - basically argued in favour of a much more flexible but not necessarily fully decentralized wage bargaining

\footnotetext{
${ }^{8}$ Source: Scheremet (1995), table 2.

${ }^{9}$ See, for example, Berthold and Fehn (1996).
} 
Table 1: Coverage of Collective Bargaining 1997

\begin{tabular}{|l|c|c|c|c|}
\hline \multirow{2}{*}{ Sector } & \multicolumn{2}{|c|}{ Firms } & \multicolumn{2}{c|}{ Employees } \\
\cline { 2 - 5 } & $\begin{array}{c}\text { West } \\
\text { Germany }\end{array}$ & $\begin{array}{c}\text { East } \\
\text { Germany }\end{array}$ & $\begin{array}{c}\text { West } \\
\text { Germany }\end{array}$ & $\begin{array}{c}\text { East } \\
\text { Germany }\end{array}$ \\
\hline mining, energy & 52.4 & 52.2 & 71.4 & 84.6 \\
basic materials & 60.6 & 31.2 & 77.7 & 52.8 \\
investment goods & 58.2 & 34.9 & 77.4 & 43.2 \\
consumption goods & 73.0 & 42.3 & 77.2 & 46.2 \\
construction & 70.2 & 40.6 & 85.3 & 49.8 \\
trade & 54.2 & 23.8 & 69.2 & 47.0 \\
transportation & 36.5 & 25.1 & 44.6 & 42.5 \\
banks/insurance & 61.0 & 44.5 & 83.8 & 88.1 \\
average & 49.0 & 25.7 & 65.3 & 43.9 \\
\hline
\end{tabular}

Source: Bellmann, Kohaut, Schnabel (1998).

system. ${ }^{10}$ The arguments put forward are that, despite the firm specific flexibility of fully decentralized wage bargaining, there are serious deficiencies of that system:

(i) Wage bargaining is a battle over claims. The resulting conflicts are passed on from collective wage determination to the firm, having adverse consequences for the working atmosphere and productivity. This becomes more important the more aggressive the workers' council negotiates with the management.

(ii) It may be correct that fully decentralized wage bargaining leads to more wage moderation in the presence of economic difficulties. But this effect is not asymmetric. The same firm experiences stronger and faster wage increases during an economic recovery. The relevant issue is therefore the net effect. For the US, a study by Bell and Freeman (1985) concludes that "the flexibility of industry wages to industry productivity has been harmful to employment" (p. 126).

(iii) As is evidenced by a number of recent contracts in Germany at the firm level, parties agree upon wage moderation and a denouncement of layoffs. In virtually no case was there a settlement which specified wage moderation and, in exchange, a number of new work places. This is exactly what the Insider-Outsider theory

\footnotetext{
${ }^{10}$ German Council of Economic Experts (1996), paragraph 326, and Franz (1995).
} 
would predict. More wage moderation in order to create more jobs is more likely to take place in collective wage bargaining.

(iv) Wage bargaining on the firm level means that the workers' council demands to be fully informed about the economic situation of the firm. Since it is unlikely that this information is kept secret, competing firms will get potentially important insights. More specifically, an unusually modest wage contract (compared with the average in that sector) may give the impression (justified or not) of firmspecific difficulties and may worsen the situation if, for example, customers and suppliers of the firm lose confidence.

Despite these advantages of some degree of centralization, collective wage agreements need sufficient flexibility in order to meet firm specific requirements. This flexibility can be achieved when the collective agreement allows for firm specific divergent rules under certain circumstances e.g. if the economic situation of the firm worsens (in the forseeable future) provided that the management, the workers' council, and the majority of the employees agree upon breaking the rules of the collective wage settlement. In such a situation, the parties have to be aware of the fact that firm specific troubles will become public knowledge, which may be the lesser of two evils (especially when quite a few firms face difficulties).

\section{Theoretical Model}

The following theoretical model compares average employment for the case of firmlevel wage bargaining and that of industry-level wage bargaining while taking account of Insider-Outsider aspects. The model assumes that the productivity of each worker depends only upon his employment status in the previous period: Outsiders (三 workers who were unemployed in the previous period) are less productive than Insiders (三 employed workers in the previous period). The model also allows for Insiders having a larger weight than Outsiders in the union's utility function. Introducing demand uncertainty at the time of wage bargaining, the union's wage policy determines the expected number of employed workers in the current period. 
Regarding the centralization of wage bargaining (CWB), the $\mathrm{U}-$ Hypothesis of Calmfors and Driffill (1988) posits that industry-level bargaining yields inferior employment results compared to decentralized or centralized wage bargaining systems. For our purposes, we consider only "Firm-level bargaining" (FB) versus "Industry-level bargaining" (IB) as the relevant alternatives in Germany. The Insider-Outsider hypothesis consists of two parts. First, unemployed workers ("Outsiders") are less productive when hired compared to employed Insiders. And second, unions give a higher weight to the interests of Insiders compared to Outsiders.

The motivation for the theoretical model developed here is twofold. First, despite the ubiquity of the two issues in discussions of wage bargaining, we are not aware of any theoretical model of the centralization of wage bargaining taking account of Insider-Outsider aspects. Second, we would like to give some theoretical guidance to the discussion of the future of wage bargaining in Germany.

Taking a "worst-case scenario" for IB in terms of the Calmfors and Driffill hypothesis, our main result consists of the finding that Insider-Outsider aspects can reverse the ranking between FB and IB with respect to employment performance. Concretely, we can show that there exist parameter constellations under which IB leads to higher average employment compared to FB. Obviously, this is only an existence result which has to be augmented by some discussion of the circumstances under which this is likely to occur in practice. At this point of the analysis, we cannot make the case as to whether or not such circumstances are likely to prevail in Germany. Rather our purpose is to point out a possible problem when a more decentralized wage bargaining system is advocated.

In the following, this section first develops the structure of the model and then presents the main results by means of simulations.

\subsection{Structure of the Model}

The model compares FB and IB considering Insider-Outsider aspects in wage bargaining. We assume an economy consisting of a sufficiently large number of small industries 
such that IB for the individual industry does not internalize macroeconomic externalities of wage bargaining on the price level or on unemployment benefits. Thus, we consider a worst-case scenario for IB in terms of the Calmfors and Driffill hypothesis. For simplicity, we study the monopoly union case with employment being determined at the firm level. However, the qualitative aspects of the results are likely to hold in more general bargaining situations. FB is modelled such that a company union maximizes its utility conditional on the number of Insiders in the firm. IB sets a uniform wage across all firms in an industry.

Further crucial features of the model are that wages are set before the uncertainty of product demand is resolved whereas employment is determined by the firm afterwards. This captures the empirical observation that wage bargaining sets wages for longer time intervals compared to the frequency by which employment is changed at given wages. Given wages in each period, employment is the outcome of static profit maximization. The dynamics of the model arise from the fact that employment in one period determines the number of Insiders in the next period. In addition, we consider whether union wage setting takes account of the dynamics of insider dynamics. As two extreme cases, we analyze myopic unions only. We accommodate the static employment effects of wage setting. Also, we allow for unions with a long-run perspective taking account of the employment effects in the steady state of the model.

\subsubsection{Assumptions of the Model}

We make the following assumptions:

A.1 Firms are continuously distributed on the interval $[0,1]$ in a small industry.

A.2 Each firm can employ zero, one, or two workers.

A.3 Each firm inherits zero, one, or two workers (Insiders) from the previous period.

A.4 Unemployed Outsiders become Insiders after one period of employment and employed Insiders become Outsiders after one period of unemployment. 
A.5 All workers are alike ex ante with respect to their productivity, i.e. all workers with the same employment status in the previous period exhibit the same productivity in the current period.

A.6 The labour force is sufficiently large.

A.7 Monopolistic competition prevails on commodity markets with demand uncertainty.

A.8 Wages are set before demand uncertainty is resolved.

A.9 Firms choose employment to maximize short-run profits after demand uncertainty is resolved.

\subsubsection{Labour Demand}

Assuming monopolistic competition on output markets, each firm faces an output demand function

$$
y^{d}(p)=\tilde{\theta} \cdot\left(\frac{p}{\bar{p}}\right)^{-\tilde{\alpha}}
$$

with $\tilde{\alpha}>1$ : price elasticity of output demand;

$p \quad$ : price of the good produced by the firm;

$\bar{p} \quad$ : average price level in the economy which is not affected by the small industry;

$\tilde{\theta} \quad$ : random output demand shock.

Then, total revenue of the firm with production $y$ is given by:

$$
p^{d}(y) \cdot y=\bar{p} \cdot \tilde{\theta}^{1 / \tilde{\alpha}} \cdot y^{1-1 / \tilde{\alpha}}=\bar{p} \cdot \theta \cdot y^{\alpha}
$$

with $p^{d}(y) \quad:$ inverse of output demand;

$\theta=\tilde{\theta}^{1 / \tilde{\alpha}} \quad:$ transformed demand shock;

$\alpha=1-1 / \tilde{\alpha}:$ elasticity of revenue in reaction to changes in output sold with $\alpha \in[0,1]$. 
Table 2: Short-run profits $\left(S P_{i, j}\right)$ of the firm ${ }^{a}$

\begin{tabular}{|c|ccc|}
\hline $\begin{array}{c}\text { Number of employees } \\
\text { in the previous period } \\
\text { Insiders } \bar{L}_{I}=i\end{array}$ & \multicolumn{3}{|c|}{$\begin{array}{c}\text { Employees in the current period: } \\
L=L_{I}+L_{O}=j\end{array}$} \\
\hline 0 & 0 & 1 & 2 \\
1 & 0 & $\theta \cdot \bar{p} \cdot \pi^{\alpha}-w_{0}$ & $\theta \cdot \bar{p} \cdot[2 \pi]^{\alpha}-2 \cdot w_{0}$ \\
2 & 0 & $\theta \cdot \bar{p}-w_{1}$ & $\theta \cdot \bar{p} \cdot[1+\pi]^{\alpha}-2 \cdot w_{1}$ \\
& 0 & $\theta \cdot \bar{p}-w_{2}$ & $\theta \cdot \bar{p} \cdot 2^{\alpha}-2 \cdot w_{2}$ \\
\hline
\end{tabular}

a: The entries in the table provide short-run profits $S P_{i, j}$ for $j$ employees in the current period conditional on the number of Insiders $\bar{L}_{I}=i$ and conditional on the wage set $\left(w_{i}\right)$.

As additional assumption, we posit

A.10 The demand shock $\theta$ is exponentially distributed with expected value unity which can be interpreted as an aggregate demand index.

The production function is given by $y=L_{e}$ where $L_{e}$ represents the efficiency units of labour such that

$$
L_{e}=L_{I}+\pi \cdot L_{O} \quad(0<\pi \leq 1)
$$

with $L_{I} \quad$ : number $(0,1,2)$ of employed Insiders;

$L_{O} \quad$ : number $(0,1,2)$ of employed Outsiders;

$\pi \quad$ : productivity of Outsiders relative to Insiders.

Then, total revenue is given by

$$
R(y)=\bar{p} \cdot \theta \cdot y^{\alpha}=\bar{p} \cdot \theta \cdot L_{e}^{\alpha} .
$$

Firms determine labour demand after the resolution of demand uncertainty, i.e. when $\theta$ is known. Table 2 specifies short-run profits conditional on the number of employees in the previous period $\bar{L}_{I}$ (Insiders) and conditional on the wage set prior to the resolution of demand uncertainty. Then, labour demand $L_{i}\left(w_{i}, \theta\right)$ is determined such that shortrun profits are maximized, i.e. $(i, j \in\{0,1,2\})$

$$
L_{i}\left(w_{i}, \theta\right)=\underset{\{j\}}{\operatorname{argmax}} S P_{i, j} \quad .
$$




\subsubsection{Stationary Markov Process in Employment for given Wages}

For given $\theta$, equation (5) defines the transition from period to period in the number of Insiders $\bar{L}_{I}$ since the employees in the current period $L_{i}$ become the Insiders of the next period. Considering the distributional assumption about the demand shock $\theta$, the transition probabilites $P T_{(i, j)}, i, j=0,1,2$, prior to the resolution of the uncertainty are given by the transition matrix

$$
P T_{(i, j)}=\left(\begin{array}{ccc}
1-\exp \left(\frac{-w_{0}}{\bar{p} \cdot \pi^{\alpha}}\right) & \exp \left(\frac{-w_{0}}{\bar{p} \cdot \pi^{\alpha}}\right)-\exp \left(\frac{-w_{0}}{\bar{p} \cdot \pi^{\alpha} \cdot\left(2^{\alpha}-1\right)}\right) & \exp \left(\frac{w_{0}}{\bar{p} \cdot \pi^{\alpha} \cdot\left(2^{\alpha}-1\right)}\right) \\
1-\exp \left(\frac{-w_{1}}{\bar{p}}\right) & \exp \left(\frac{-w_{1}}{\bar{p}}\right)-\exp \left(\frac{-w_{1}}{\bar{p} \cdot\left([1+\pi]^{\alpha}-1\right)}\right) & \exp \left(\frac{-w_{1}}{\bar{p} \cdot\left([1+\pi]^{\alpha}-1\right)}\right) \\
1-\exp \left(\frac{-w_{2}}{\bar{p}}\right) & \exp \left(\frac{-w_{2}}{\bar{p}}\right)-\exp \left(\frac{-w_{2}}{\bar{p} \cdot\left(2^{\alpha}-1\right)}\right) & \exp \left(\frac{-w_{2}}{\bar{p} \cdot\left(2^{\alpha}-1\right)}\right)
\end{array}\right)
$$

which defines a first-order stationary Markov process (Markov chain) ${ }^{11}$ in the number of Insiders $\bar{L}_{i}$, where $P T_{(i, j)}$ represents the probability that a firm with $\bar{L}_{I}=i$ Insiders has $L=j$ employees. The first line of $P T\left(\bar{L}_{I}=0\right)$ can be derived by noting that $\{L=0\}$ is equivalent to $\left\{\theta<\frac{w_{0}}{\bar{p} \cdot \pi^{\alpha}}\right\}$ with ex ante probability

$$
\operatorname{Prob}\left(L=0 \mid \bar{L}_{I}=0\right)=P T_{0,0}=\int_{0}^{\frac{w_{0}}{\bar{p} \cdot \pi^{\alpha}}} \exp (-\theta) d \theta
$$

and that $\{L=1\}$ is equivalent to $\left\{\frac{w_{0}}{\bar{p} \cdot \pi^{\alpha}}<\theta<\frac{w_{0}}{\bar{p} \cdot \pi^{\alpha} \cdot\left(2^{\alpha}-1\right)}\right\}$ with ex ante probability

$$
\operatorname{Prob}\left(L=1 \mid \bar{L}_{I}=0\right)=P T_{0,1}=\int_{\frac{w_{0}}{\bar{p} \cdot \pi^{\alpha}}}^{\frac{w_{0}}{\bar{p} \cdot\left(2^{\alpha}-1\right)}} \exp (-\theta) d \theta
$$

and that $\operatorname{Prob}\left(L=2 \mid \bar{L}_{I}=0\right)=P T_{0,2}=1-P T_{0,0}-P T_{0,1}$. The other entries can be derived analogously.

For a specific parameter constellation $(\alpha=0.3, \pi=0.6)$, figure 1 in the appendix depicts the expected labour demand schedule $E L_{i}=P T_{(i, 1)}+2 \cdot P T_{(i, 2)}$ before the resolution of demand uncertainty as a function of $w_{i}$ depending on the number of Insiders, $\bar{L}_{I}=i$. Most important for our results is the fact that the expected labour demand schedule for the firms with one Insider $\bar{L}_{I}=1$ is steeper than for the other firms and that it can even lie below the schedule for the firm with no Insiders. This is due to the fact that the Outsider in the firm with one Insider displays a particulary low marginal product.

\footnotetext{
${ }^{11}$ See Karlin and Taylor (1975) for a textbook treatment.
} 
For given wages $\left(w_{0}, w_{1}, w_{2}\right), P T$ defines a stationary Markov process in the distribution of firms with zero, one, or two employees $\left(P_{0}, P_{1}, P_{2}\right)$ (Insiders of the next period) with the following transition equation

$$
\left(P_{0}, P_{1}, P_{2}\right)_{t}=\left(P_{0}, P_{1}, P_{2}\right)_{t-1} \cdot P T
$$

Since PT contains no zeroes as entries, there exists exactly one stationary distribution of firms $\left(P_{0}^{*}, P_{1}^{*}, P_{2}^{*}\right)$ as the fixed point of the transition process

$$
\left(P_{0}^{*}, P_{1}^{*}, P_{2}^{*}\right)=\left(P_{0}^{*}, P_{1}^{*}, P_{2}^{*}\right) \cdot P T
$$

The stationary distribution is also stable, i.e.

$$
\lim _{t \rightarrow \infty}\left(P_{0}, P_{1}, P_{2}\right)_{t}=\left(P_{0}^{*}, P_{1}^{*}, P_{2}^{*}\right)
$$

irrespective of the starting distribution..$^{12}$

The comparative statics of $\left(P_{0}^{*}, P_{1}^{*}, P_{2}^{*}\right)$ with respect to changes in $\left(w_{0}, w_{1}, w_{2}\right)$ are obtained by totally differentiating equation (7). It is clear that (proofs are available upon request)

$$
\frac{\partial P_{0}^{*}}{w_{0}}>0, \frac{\partial P_{0}^{*}}{w_{1}}>0, \frac{\partial P_{0}^{*}}{w_{2}}>0, \frac{\partial P_{2}^{*}}{w_{0}}<0, \frac{\partial P_{2}^{*}}{w_{1}}<0, \text { and } \frac{\partial P_{2}^{*}}{w_{2}}<0
$$

since a higher wage increases the transition probability towards zero Insiders and decreases the transition probability towards two Insiders in all states. The effects on $P_{1}^{*}$ depend upon the relative size of the wages. Generally, for $w_{i}$ small, it is the case that $\frac{\partial P_{1}^{*}}{w_{i}}>0$, and for $w_{i}$ large, that $\frac{\partial P_{1}^{*}}{w_{i}}<0$. However, this effect can be counteracted by the indirect propagation via the other states $\bar{L}_{I}=0,2$. For example, if $w_{2}$ is relatively large and both $w_{0}$ and $w_{1}$ are relatively small, an increase in $w_{2}$ can lead to an increase in the steady state probability of one Insider $P_{1}^{*}$.

Concluding, it should be noted that the transition matrix $P T$ and the stationary distribution $\left(P_{0}^{*}, P_{1}^{*}, P_{2}^{*}\right)$ effectively depend upon real wages $w_{i} / \bar{p}$ inheriting this property from labour demand.

\footnotetext{
${ }^{12}$ See Theorem 1.3 in Karlin and Taylor (1975, p. 85).
} 


\subsubsection{Wage Setting}

The firm wage or industry wages are set by a monopoly union before demand uncertainty $\theta$ is resolved. We make the following crucial further assumptions:

A.11 Employed Insiders and employed Outsiders $\left(L=L_{I}+L_{O}\right)$ receive the same wage in a firm set by wage bargaining and the union cares more about employment of Insiders compared to Outsiders.

A.12 The firm cannot replace Insiders by Outsiders, i.e. Outsiders are only employable when all Insiders remain employed.

These assumptions characterize the Insider-Outsider problem. Unions set the same wage for both groups of workers (A.11) even though the productivity of Outsiders is less in the short run (equation 3) and firms cannot replace all Insiders by Outsiders - presumably the latter demand a lower wage $w_{0}$ - due to prohibitive organizational $\operatorname{costs}(\mathrm{A} .12) .{ }^{13}$

The union utility function is given by:

$$
V\left(L_{I}, L_{O}, w\right)=E_{\theta}\left(L_{I}+g \cdot L_{O}\right) \cdot(w / \bar{p}-b)^{\beta}
$$

with $g$ : weight of employed Outsiders relative to employed Insiders with $0 \leq g \leq 1$

$b$ : real level of alternative income not affected by the small industry;

$\beta$ : weight of wage relative to expected weighted employment argument with $\beta>0$.

This cardinal utility function is formulated such that the union is risk neutral towards the variation of employment. Thus, we ignore the possibility that the lower variance of employment at the industry level exerts an independent effect on wage setting. This assumption simplifies aggregation of preferences for the industry-level union setting a uniform wage such that the utility of the industry-level union simply depends upon total weighted employment.

\footnotetext{
${ }^{13}$ These assumptions are quite restrictive in light of the recent experience in Germany, since firms often outsource activities in order to incur lower cost and these activities are purchased from newly established firms. Thus, assumptions A.11 and A.12 serve as a benchmark for the analysis of the Insider-Outsider problem.
} 
With regard to the centralization of wage bargaining (CWB), we consider the alternatives:

FB: Decentralized wage bargaining ("Firm-level bargaining") where wages are set separately for each firm;

IB: Industry-level wage bargaining setting a uniform wage for all firms in the industry.

In addition, we also consider whether the union maximizes its objective myopically (i.e. for the current period taking the number of Insiders as given) or whether it has a long-run orientation maximizing its objective in the steady state. Taking the latter perspective, the union effectively takes account of the wage effects on the steady state distribution of Insiders $\left(P^{*}\left(w_{0}, w_{1}, w_{2}\right)\right)$ in addition to the direct utility effects of wages and current employment. Overall, we consider the following four scenarios for wage setting which we afterwards describe in detail:

\begin{tabular}{|c|cc|}
\hline \multirow{2}{*}{ CWB } & \multicolumn{2}{|c|}{ Orientation of Union } \\
\cline { 2 - 3 } & Myopic & Long-Run \\
\hline Firm level & FB-Myopic & FB-Long-Run \\
Industry level & IB-Myopic & IB-Long-Run \\
\hline
\end{tabular}

FB-Myopic: Depending on the number of Insiders, $\bar{L}_{I}=i$, the firm-level union maximizes

$$
\begin{gathered}
\max _{\left\{w_{i}\right\}} V_{i}(w)=E_{\theta}\left(L_{I}+g \cdot L_{O}\right) \cdot\left(w_{i} / \bar{p}-b\right)^{\beta} \\
\text { subject to }: E_{\theta}\left(L_{I}+g \cdot L_{O}\right)= \begin{cases}g \cdot P T_{(0,1)}+2 \cdot g \cdot P T_{(0,2)} & \text { for } i=0 \\
P T_{(1,1)}+(1+g) \cdot P T_{(1,2)} & \text { for } i=1 \\
P T_{(2,1)}+2 \cdot P T_{(2,2)} & \text { for } i=2\end{cases}
\end{gathered}
$$

The wage is set by the union to satisfy the following standard first-order condition

$$
\begin{gathered}
\frac{\partial V_{i}(w)}{\partial w}=\frac{\partial E\left(L_{I}+g \cdot L_{O}\right)}{\partial w_{i}} \cdot\left(w_{i} / \bar{p}-b\right)^{\beta} \\
+\beta \cdot E\left(L_{I}+g \cdot L_{O}\right) \cdot\left(w_{i} / \bar{p}-b\right)^{\beta-1} \cdot \bar{p}^{-1}=0
\end{gathered}
$$

where $V_{i}(w)$ incorporates the labour demand constraint. The first-order condition implies that the marginal benefit of a higher wage is equal to the marginal costs in 
form of lost expected weighted employment. Due to the smoothness assumptions made above, a unique solution of equation (8) always exists corresponding to the utility maximum. Since $E\left(L_{I}+g \cdot L_{O}\right)$ depends upon $w_{i} / \bar{p}$, the union effectively sets a real wage which is unaffected by changes in the average price level $\bar{p}$.

Since wage setting in each firm does not depend upon the overall shares of firms with zero, one, or two Insiders, this wage setting behaviour under FB-Myopic $W^{f b m}=$ $\left(w_{0}^{f b m}, w_{1}^{f b m}, w_{2}^{f b m}\right)$ does not change during the transition process in employment implying a stationary Markov process according to equation (6). Thus, FB-Myopic involves a stationary Markov process and convergence to a unique steady state distribution of employment

$$
P^{*}\left(W^{f b m}\right)=\left(P_{0}^{*}\left[W^{f b m}\right], P_{1}^{*}\left[W^{f b m}\right], P_{2}^{*}\left[W^{f b m}\right]\right)
$$

One can show the following comparative static results for the steady state distribution (9) $\frac{\partial w_{i}^{f b m}}{\partial g} \leq 0, \frac{\partial w_{i}^{f b m}}{\partial \beta}>0, \frac{\partial E L^{f b m}}{\partial g} \geq 0, \frac{\partial E L^{f b m}}{\partial \beta}<0$, and $\frac{\partial E L^{f b m}}{\partial \pi} \geq 0$,

none of which are surprising. For example, wage demands are moderated when the weight $g$ of Outsiders increases and when the weight of wages in the utility function $\beta$ decreases. Average total employment depends positively upon $g$ and the relative productivity of Outsiders, $\pi$, and negatively on $\beta$. For example, the $g$-effect can be be explained intuitively by noting that an increase of $g$ reduces the marginal utility of a wage increase since the implied employment loss of the Outsiders carries a larger weight.

IB-Myopic: Depending on the distribution of firms with zero, one, or two Insiders, $\left(P_{0, t-1}, P_{1, t-1}, P_{2, t-1}\right)$, the industry-level union sets a uniform wage $w$ according to

$$
\begin{gathered}
\max _{\{w\}} V I\left(L_{I}, L_{O}, w\right)=E_{\theta}\left(L_{I}+g \cdot L_{O}\right) \cdot(w / \bar{p}-b)^{\beta} \\
=P_{0, t-1} \cdot V_{0}(w)+P_{1, t-1} \cdot V_{1}(w)+P_{2, t-1} \cdot V_{2}(w)
\end{gathered}
$$

where $V_{i}, i=0,1,2$, is the utility function in the case FB-Myopic. Here, there exists no incentive for firms to replace Insiders by Outsiders. The optimal wage satisfies the first order condition

$$
P_{0, t-1} \cdot \frac{\partial V_{0}(w)}{\partial w}+P_{1, t-1} \cdot \frac{\partial V_{1}(w)}{\partial w}+P_{2, t-1} \cdot \frac{\partial V_{2}(w)}{\partial w}=0
$$


Since the wage set depends upon the distribution $\left(P_{0, t-1}, P_{1, t-1}, P_{2, t-1}\right)$ of the previous period, equation (6) now defines a non-stationary Markov process in the distribution of firms with zero, one, and two Insiders. This nonlinear difference equation could imply stable limit cycles or even chaotic behaviour, see Schröder (1985). However, for all the parameter constellations considered in this paper, we did find by simulation a unique stable limit distribution without cycles and no chaotic behaviour. Let $w^{i b m}$ be the limit wage and $E L^{i b m}$ be the expected employment in the steady state.

Again as to be expected, we find the same qualitative comparative static results as in equation (9) for FB-Myopic with $w_{i}^{f b m}$ being replaced by $w^{i b m}$ and all inequalities becoming strict.

IB-Long-Run: Here, the industry-level union sets a uniform wage $w$ taking into account the long-run repercussions on the steady state employment distribution $\left(P_{0}^{*}, P_{1}^{*}\right.$, $\left.P_{2}^{*}\right)$, i.e. the union maximizes

$$
\begin{aligned}
& \max _{\{w\}} V I\left(L_{I}, L_{O}, w\right)=E_{\theta}\left(L_{I}+g \cdot L_{O}\right) \cdot(w / \bar{p}-b)^{\beta} \\
& =P_{0}^{*}(w) \cdot V_{0}(w)+P_{1}^{*}(w) \cdot V_{1}(w)+P_{2}^{*}(w) \cdot V_{2}(w)
\end{aligned}
$$

The first-order condition for the utility maximum changes to

$$
\begin{aligned}
& P_{0}^{*} \cdot \frac{\partial V_{0}(w)}{\partial w}+P_{1}^{*} \cdot \frac{\partial V_{1}(w)}{\partial w}+P_{2}^{*} \cdot \frac{\partial V_{2}(w)}{\partial w}+ \\
& \frac{\partial P_{0}^{*}}{\partial w} \cdot V_{0}(w)+\frac{\partial P_{1}^{*}}{\partial w} \cdot V_{1}(w)+\frac{\partial P_{2}^{*}}{\partial w} \cdot V_{2}(w)=0
\end{aligned}
$$

yielding a unique optimal wage $w^{i b l}$. The union sets the same wage irrespective of the current distribution of Insiders, thus implying a stationary Markov process in employment and convergence to the corresponding steady state distribution $\left(P_{0}^{*}, P_{1}^{*}, P_{2}^{*}\right)$. It is clear that $w^{i b l}<w^{i b m}$ since the second line of the first-order condition is negative, thus implying that the wage is set at a level where the first line is positive. The argument for the second line follows due to (i) $\frac{\partial P_{0}^{*}}{\partial w}+\frac{\partial P_{1}^{*}}{\partial w}+\frac{\partial P_{2}^{*}}{\partial w}=0$, (ii) $V_{0}(w)<V_{1}(w)<V_{2}(w)$ for $g<1$ or $\pi<1$, and (iii) $\frac{\partial P_{0}^{*}}{\partial w}>0$ and $\frac{\partial P_{2}^{*}}{\partial w}<0$.

While the impact of $b$ on the wage and on expected employment still exhibit the same signs as above, it might come as a surprise that the comparative static results for $g$ and 
$\pi$ can change. In general, the effects cannot be signed due to the repercussions on the steady state distribution of employment and, for many of the parameter constellations considered in the subsequent simulation study, the signs are actually reversed compared to the myopic cases. Thus, it is possible that an increase in the weight of Outsiders $g$ or an increase in their relative productivity $\pi$ leads to lower expected employment. The ambiguity of the $g$-effect can be seen intuitively by noting that the first line of the first-order condition in equation (11) depends negatively on $g$ (as pointed out above for FB-Myopic) and the second line depends positively on $g$. The argument for the second line follows since both $V_{0}(w)$ and $V_{1}(w)$ are positively affected by $g$ and due

to point (i) and (iii) in the previous paragraph (note that $\frac{\partial P_{i}^{*}}{\partial w}, i=0,1,2$, does not depend upon $g$ ). Thus, the effect of a change in $g$ on the marginal utility of the wage is ambiguous. The ambiguity of the $\pi$-effect can be motivated in an analogous way.

FB-Long-Run: The company union taking account of the repercussions of wage setting on the steady state distribution knows that the long run distribution of Insiders in each individual firm corresponds to the steady state distribution of firms. Thus, it sets a wage schedule wage $W=\left(w_{0}, w_{1}, w_{2}\right)$ entailing the wage for all three possible numbers of Insiders a firm can have. The union maximizes

$$
\underset{\left\{w_{0}, w_{1}, w_{2}\right\}}{\max } V\left(L_{I}, L_{O}, W\right)=P_{0}^{*}(W) \cdot V_{0}\left(w_{0}\right)+P_{1}^{*}(W) \cdot V_{1}\left(w_{1}\right)+P_{2}^{*}(W) \cdot V_{2}\left(w_{2}\right) .
$$

It is assumed that the unions sets the same wage schedule irrespective of the current distribution of Insiders, thus again implying a stationary Markov process in employment and convergence to the corresponding steady state distribution $\left(P_{0}^{*}, P_{1}^{*}, P_{2}^{*}\right)$. It is clear that $w^{f b l}<w^{f b m}$ for the same reason as in the case of IB. Again, the signs of the impact of $b$ and wages and employment remain unchanged compared to the myopic case and the signs for $g$ and $\pi$ become ambiguous.

\subsection{Simulation Results for the Steady State}

This section provides simulation results for different parameter values on the relative performance of the wage setting regimes in terms of the average steady state employment levels implied. Since labour demand and union utility depend upon real wages, 
it is without loss of generality to set $\bar{p}$ equal to unity. ${ }^{14}$ Thus, in this paper, we do not consider the possibility that, with a higher CWB, the union internalizes the price effects of wage setting, which, by itself, would lead to lower real wages and higher employment levels. In this sense, our analysis provides a worst-case-scenario for IB in the light of the Calmfors-Driffill hypothesis.

As the main theoretical result of this paper, it is shown here that, if one compares firmlevel bargaining (FB) and industry-level bargaining (IB), while assuming the same parameter values and either myopic or long-run orientation in both cases, the ranking with respect to employment is ambiguous. Since this ambiguity result cannot easily be derived analytically and since it is easily established by presenting two parameter constellations with opposite results, we resort to simulation methods to investigate how this effect depends upon the parameters:

- $\alpha$ : Elasticity of total revenue with respect to changes of employment in efficiency units

- $\pi$ : Productivity of Outsiders relative to Insiders

- $g$ : Weight of Outsiders relative to Insiders in union utility

- $\beta$ : Weight of wage relative to weighted employment in union utility

- $b$ : Real alternative income level

The calculation of the steady state distribution is straightforward in the cases FBMyopic, FB-Long-Run, and IB-Long-Run, since wage setting does not depend upon the current distribution of Insiders. Thus, the implied Markov process is stationary and exhibits a unique stable fixed point. In the case of IB-Long-Run, the situation is more complicated. Here, wage setting depends upon the current distribution of Insiders and therefore the implied Markov process becomes non-stationary. In such a case, it is theoretically possible that the steady state distribution is non-unique and there exists a limit cycle or even chaotic behaviour, see e.g. Schröder (1985). However,

\footnotetext{
${ }^{14}$ In the model presented in Calmfors and Driffill (1988), nominal wage and price levels play a role because aggregate nominal demand is fixed.
} 
Table 3: Expected Steady State Employment for $b=0^{a}$

\begin{tabular}{ccccc}
\hline$g$ & FB-Myopic & IB-Myopic & FB-Long-Run & IB-Long-Run \\
\hline \multicolumn{4}{c}{$\alpha=0.4, \pi=0.9, \beta=1$} \\
\hline 0.6 & $\mathbf{0 . 5 4 5 1 9}$ & 0.53161 & $\mathbf{0 . 7 1 5 5 9}$ & 0.69769 \\
0.7 & $\mathbf{0 . 5 5 1 3 7}$ & 0.54362 & $\mathbf{0 . 6 7 1 7 2}$ & 0.66341 \\
0.8 & $\mathbf{0 . 5 5 8 0 3}$ & 0.55439 & $\mathbf{0 . 6 3 6 2 4}$ & 0.63313 \\
0.9 & $\mathbf{0 . 5 6 5 1 5}$ & 0.56410 & $\mathbf{0 . 6 0 6 8 4}$ & 0.60636 \\
1.0 & 0.57266 & $\mathbf{0 . 5 7 2 9 2}$ & 0.58216 & $\mathbf{0 . 5 8 2 9 5}$ \\
\hline \multicolumn{5}{c}{$\alpha=0.4, \pi=0.8, \beta=1$} \\
\hline 0.6 & $\mathbf{0 . 5 3 4 2 3}$ & 0.51384 & $\mathbf{0 . 7 1 7 3 4}$ & 0.69273 \\
0.7 & $\mathbf{0 . 5 3 9 0 9}$ & 0.52653 & $\mathbf{0 . 6 7 1 3 0}$ & 0.65891 \\
0.8 & $\mathbf{0 . 5 4 4 4 9}$ & 0.53800 & $\mathbf{0 . 6 3 4 1 0}$ & 0.62849 \\
0.9 & $\mathbf{0 . 5 5 0 4 7}$ & 0.54844 & $\mathbf{0 . 6 0 3 2 1}$ & 0.60201 \\
1.0 & 0.55706 & $\mathbf{0 . 5 5 7 9 8}$ & 0.57708 & $\mathbf{0 . 5 7 8 1 3}$ \\
\hline \multicolumn{5}{c}{$\alpha=0.5, \pi=0.9, \beta=1$} \\
\hline 0.6 & $\mathbf{0 . 6 2 3 5 3}$ & 0.61530 & $\mathbf{0 . 8 0 0 9 2}$ & 0.78553 \\
0.7 & $\mathbf{0 . 6 2 9 7 9}$ & 0.62521 & $\mathbf{0 . 7 5 4 8 9}$ & 0.74788 \\
0.8 & $\mathbf{0 . 6 3 5 9 7}$ & 0.63378 & $\mathbf{0 . 7 1 7 7 8}$ & 0.71422 \\
0.9 & $\mathbf{0 . 6 4 2 0 1}$ & 0.64128 & $\mathbf{0 . 6 8 7 2 4}$ & 0.68636 \\
1.0 & 0.64786 & $\mathbf{0 . 6 4 7 9 0}$ & 0.66210 & $\mathbf{0 . 6 6 1 7 4}$ \\
\hline \multicolumn{5}{c}{$\alpha=0.4, \pi=0.9, \beta=0.5$} \\
\hline 0.6 & 1.11784 & $\mathbf{1 . 1 1 8 1 4}$ & 1.30584 \\
0.7 & $\mathbf{1 . 1 2 9 7 4}$ & 1.12972 & 1.26909 & $\mathbf{1 . 3 0 8 1 5}$ \\
0.8 & $\mathbf{1 . 1 4 0 2 0}$ & 1.13994 & 1.23265 & $\mathbf{1 . 2 3 4 8 8}$ \\
0.9 & $\mathbf{1 . 1 4 9 3 6}$ & 1.14904 & 1.19965 & $\mathbf{1 . 2 0 1 2 4}$ \\
1.0 & $\mathbf{1 . 1 5 7 4 0}$ & 1.15721 & 1.16685 & $\mathbf{1 . 1 7 0 6 6}$ \\
\hline
\end{tabular}

a: For each scenario, the bold number indicates which bargaining system leads to higher employment.

for all parameter constellations considered here, we find a unique stable steady state distribution and no cycles. This is established by starting the process at the three extreme distributions, i.e. one of the three probabilities $P_{i}, i=0,1,2$, is set to unity, which always results in the same non-cyclical limit distribution. This special treatment of the non-stationary process in the case of IB-Myopic provides a second reason for using simulation methods.

Tables 3 and 4 provide expected total employment (Insiders plus Outsiders with equal weight) for $b=0$ and $b=0.2$, respectively. Further, we present results for the following parameter constellations: $\alpha=0.4,0.5, \pi=0.8,0.9, \beta=0.5,1.0$, and $g=0.6, \ldots, 1.0$. Our goal is rather to show what can happen for a somewhat realistic setup but not 
Table 4: Expected Steady State Employment for $b=0.2^{a}$

\begin{tabular}{ccccc}
\hline$g$ & FB-Myopic & IB-Myopic & FB-Long-Run & IB-Long-Run \\
\hline \multicolumn{4}{c}{$\alpha=0.4, \pi=0.9, \beta=1$} \\
\hline 0.6 & $\mathbf{0 . 3 8 1 3 7}$ & 0.37389 & $\mathbf{0 . 4 7 5 4 2}$ & 0.46062 \\
0.7 & $\mathbf{0 . 3 8 3 3 2}$ & 0.37866 & $\mathbf{0 . 4 4 8 2 2}$ & 0.44092 \\
0.8 & $\mathbf{0 . 3 8 5 3 9}$ & 0.38282 & $\mathbf{0 . 4 2 6 8 8}$ & 0.42357 \\
0.9 & $\mathbf{0 . 3 8 7 5 6}$ & 0.38648 & $\mathbf{0 . 4 0 9 7 2}$ & 0.40852 \\
1.0 & $\mathbf{0 . 3 8 9 8 4}$ & 0.38973 & $\mathbf{0 . 3 9 5 5 5}$ & 0.39535 \\
\hline \multicolumn{5}{c}{$\alpha=0.4, \pi=0.8, \beta=1$} \\
\hline 0.6 & $\mathbf{0 . 3 7 2 3 2}$ & 0.36066 & $\mathbf{0 . 4 7 3 5 4}$ & 0.45216 \\
0.7 & $\mathbf{0 . 3 7 3 6 9}$ & 0.36571 & $\mathbf{0 . 4 4 5 2 8}$ & 0.43296 \\
0.8 & $\mathbf{0 . 3 7 5 1 3}$ & 0.37012 & $\mathbf{0 . 4 2 3 0 6}$ & 0.41630 \\
0.9 & $\mathbf{0 . 3 7 6 6 5}$ & 0.37400 & $\mathbf{0 . 4 0 5 0 9}$ & 0.40170 \\
1.0 & $\mathbf{0 . 3 7 8 2 6}$ & 0.37745 & $\mathbf{0 . 3 9 0 2 3}$ & 0.38891 \\
\hline \multicolumn{5}{c}{$\alpha=0.5, \pi=0.9, \beta=1$} \\
\hline 0.6 & $\mathbf{0 . 4 4 6 1 1}$ & 0.43941 & $\mathbf{0 . 5 4 8 2 0}$ & 0.53593 \\
0.7 & $\mathbf{0 . 4 4 9 0 7}$ & 0.44517 & $\mathbf{0 . 5 2 0 2 7}$ & 0.51434 \\
0.8 & $\mathbf{0 . 4 5 2 0 4}$ & 0.45008 & $\mathbf{0 . 4 9 8 5 3}$ & 0.49588 \\
0.9 & $\mathbf{0 . 4 5 5 0 2}$ & 0.45431 & $\mathbf{0 . 4 8 0 9 3}$ & 0.48005 \\
1.0 & 0.45797 & $\mathbf{0 . 4 5 8 0 0}$ & $\mathbf{0 . 4 6 6 3 8}$ & 0.46637 \\
\hline \multicolumn{5}{c}{$\alpha=0.4, \pi=0.9, \beta=0.5$} \\
\hline 0.6 & $\mathbf{0 . 7 4 0 8 7}$ & 0.73690 & $\mathbf{0 . 8 3 6 6 1}$ & 0.83351 \\
0.7 & $\mathbf{0 . 7 4 7 4 9}$ & 0.74546 & 0.81709 & $\mathbf{0 . 8 1 8 4 4}$ \\
0.8 & $\mathbf{0 . 7 5 3 7 8}$ & 0.75290 & 0.79978 & $\mathbf{0 . 8 0 0 3 4}$ \\
0.9 & $\mathbf{0 . 7 5 9 6 9}$ & 0.75945 & 0.78429 & $\mathbf{0 . 7 8 6 2 9}$ \\
1.0 & 0.76522 & $\mathbf{0 . 7 6 5 2 6}$ & 0.77033 & $\mathbf{0 . 7 7 3 4 2}$ \\
\hline
\end{tabular}

a: For each scenario, the bold number indicates which bargaining system leads to higher employment.

to argue which parameter constellation is the empirically valid one. Simulation results for further scenarios are obtained and available upon request. The results presented here highlight the important features of the model in terms of expected steady state employment levels.

Starting with the first three parameter constellations in table 3, it is assumed here that the union maximizes the expected weighted wage bill $(\beta=1)$ implying equal weighting between employment of Insiders and wages. For the myopic unions, it is clear that FB leads to higher employment compared to IB except for $g$ close to unity. Thus, we have already obtained the main result of the analysis, namely that everything else equal it is possible that IB results in higher employment compared to FB. Apparently, the 
difference between FB and IB is reduced with higher g, i.e. the relative employment performance of IB improves when the union cares more about the Outsiders. Results not presented here, show that the break-even point is strictly below unity. As pointed out in section 3.1.4, employment increases with a higher $g$, a higher $\pi$, or a higher $\alpha$. A long-run orientation of wage bargaining leads uniformly to higher employment, as pointed out in section 3.1.4, but for $\beta=1$ the qualitative ranking between $\mathrm{FB}$ and IB remains the same. Results not presented here show that for a long-run orientation it is also possible both for FB and IB that employment is lower with a higher $\pi$ (in contrast to the cases considered in tables 3 and 4 ).

When the union attaches a relatively higher weight to employment $\beta=0.5$, the situation changes completely. As it is clear from the theoretical analysis, average employment is higher compared to $\beta=1$. However, the relative employment performance as a function of $g$ can be reversed. Now, in the myopic case, IB leads to higher employment for $g=0.6$ compared to FB but to lower employment for higher values of $g$. For a long-run orientation, however, IB now outperforms FB in all presented cases. Thus, while the influence of $g$ on the relative performance is ambiguous, it seems to be the case that it is more likely for IB-Long-Run to outperform FB-Long-Run the lower the weight of wages in the union objective. The latter is confirmed by simulation results for other parameter constellations.

When the alternative income increases from $b=0$ to $b=0.2$, table 4 mainly shows the same qualitative pattern as table 3 . However, the relative performance of IB deteriorates, e.g. for $\beta=1$, we find only for $\alpha=0.5, \pi=0.9$, and $g=1.0$ a superior performance of IB in the myopic case. With higher weight of employment $(\beta=0.5)$, IB-Long-Run still outperforms FB-Long-Run for $g>0.6$. In contrast to table 3, it should be noted, that the qualitative ranking between FB-Myopic and IB-Myopic now depends positively upon $g$ for the case $\beta=0.5$. The deterioration of the relative performance of IB with a higher alternative income is analogous to an increase of the relative weight of the wage in the union utility function $\beta$. In both cases, the marginal utility derived from of a higher wage increases, thus apparently improving the relative performance of $\mathrm{FB}$. 
Summing up the simulation results, we have shown the following points in addition to the results known unambiguously from the theoretical analysis. First, it depends on the choice of parameter values whether IB or FB leads to higher expected employment in the steady state. Second, a higher weight of Outsiders in union utility $g$ or a higher relative productivity $\pi$ do not necessarily lead to higher employment. For a longrun orientation of wage bargaining, employment can actually decline. Third, a higher relative weight of the wage in the union utility function or a higher alternative income tends to improve the relative performance of FB.

\section{Conclusions}

The broad-brush assessment of the German process of wage determination proceeds as follows. According to the Calmfors-Driffill-hypothesis either fully decentralized or fully centralized wage bargaining yields efficient outcomes in terms of lower real wages and, hence, higher employment. Since wage bargaining in Germany can, by and large, be described as industry-level wage bargaining there is reason to argue that German institutional regulations share major responsibility in explaining high and persistent unemployment.

Without denying obvious shortcomings of the German wage bargaining process, this paper provides a theoretical analysis which challenges the Calmfors-Driffill-model to some extent. The novelty of our study lies in an integration of Insider-Outsider aspects with theoretical considerations regarding the optimal degree of centralization of wage bargaining. From this exercise, it can be learnt that the aforementioned assessment may be too broad-brush, indeed.

More specifically, we obtain the result that industry-level wage bargaining may - but only "may" - result in higher average steady state employment compared with firmlevel wage bargaining. The judgement upon the optimal degree of centralization of wage bargaining depends on several parameter constellations of our model: A superior employment performance of industry-level wage bargaining is the more likely when unions attach a higher weight to employment relative to wages and exhibit more of 
a long-run orientation in wage bargaining. A major conclusion from the theoretical analysis is that the relative employment performance of different wage bargaining regimes cannot simply be ranked according to the degree of centralization and, in fact, the theoretical model could not take account of all the relevant aspects put forward in section 2 .

Nevertheless, it goes without saying that these findings are a major challenge to union behaviour. Obviously, unions in Germany did not meet these requirements in the past. Therefore, critics of the German wage bargaining system may be right - but for the wrong reason. It is not so much a question of the degree of centralization but more whether unions are willing to take care of the unemployed rather than to follow mainly the interests of the Insiders. Such a desirable behaviour of the unions, however, is less likely in a system of firm-level wage bargaining because employees or workers councils may view their contribution to better employment prospects by wage moderation too small to be considered seriously. These insights may be more realistic at medium levels of wage bargaining. Rather than solely trying to decentralize wage bargaining, a promising policy option may be to improve the skills of the Outsiders by efficient labour market policies and to establish a higher influence of the unemployed in the wage bargaining process by institutional reforms which at the same time should enhance the long-run orientation of wage bargaining. A higher productivity of Outsiders allows for a higher real wage at given employment levels in the steady state, thus improving the chances for the second part of this policy option. In the light of this paper, the recommended strategy hinges on the observation that wage bargaining currently does not sufficiently take into account its long-run employment effects. Despite its plausibility, this presumption needs to be investigated further empirically. 


\section{References}

Bell, L.A. and R.B. Freeman (1985). Flexible Wage Structures and Employment. In: Gunderson, M., Meltz, N., and S. Ostry (Eds.), Unemployment. International Perspectives (pp. 119-128). Toronto.

Bellmann, L., Kohaut, S., and C. Schnabel (1998). Ausmaß und Entwicklung der übertariflichen Entlohnung. iw-Trends, Institut der deutschen Wirtschaft, 25(2), $1-10$.

Berthold, N. and R. Fehn (1996). Evolution von Lohnverhandlungssystemen Macht oder ökonomisches Gesetz? In: W. Zohlnhöfer (Ed.), Die Tarifautonomie auf dem Prüfstand (pp. 57-94). Berlin.

Calmfors, L. (1993). Centralisation of Wage Bargaining and Macroeconomic Performance: A Survey. OECD, Economics Department, Working Paper, 131.

Calmfors, L. and J. Driffill (1988). Centralization of Wage Bargaining. Economic Policy, 6, 14-61.

Fitzenberger, B. and W. Franz (1994). Dezentrale versus zentrale Lohnbildung in Europa: Theoretische Aspekte und empirische Evidenz. In: Gahlen, B., Hesse, H., and Ramser, H.J. (Eds.), Europäische Integrationsprobleme aus wirtschaftswissenschaftlicher Sicht (pp. 321-353). Schriftenreihe des Wirtschaftswissenschaftlichen Seminars Ottobeuren, Band 23: J.C.B. Mohr (Paul Siebeck) Tübingen.

Franz, W. (1995). Die Lohnfindung in Deutschland in einer internationalen Perspektive: Ist das deutsche System der Lohnfindung ein Auslaufmodell? Beihefte der Konjunkturpolitik, Zeitschrift für angewandte Wirtschaftsforschung, 43, 31-57.

German Council of Economic Experts (SVR) (1996). Pushing Forward with Reforms. Annual Report 1996/97 (Sachverständigenrat zur Begutachtung der gesamtwirtschaftlichen Entwicklung). Metzler-Poeschel. Stuttgart.

Karlin, S. and H.M. Taylor (1975). A First Course in Stochastic Processes. Second Edition, Academic Press, San Diego.

Scheremet, W. (1995). Tarifpolitik in Ostdeutschland: Ausstieg aus dem Lohnverhandlungsmodell der Bundesrepublik Deutschland? Beihefte der Konjunkturpolitik, Zeitschrift für angewandte Wirtschaftsforschung, 114, 135-169.

Schröder, R. (1985). Chaotisches Verhalten von Differenzengleichungen. In: Gabisch, G. and v.Trotha, H. (Eds.), Dynamische Eigenschaften nichtlinearer Differenzengleichungen und ihre Anwendung in der Ökonomie (pp. 143-155). GMD-Studien, Nr. 97. 